\title{
Neurophysiological basis of direct cortical stimulation and applied neuroanatomy of the motor cortex: a review
}

\author{
Theodoros Kombos, M.D., and Olaf Süss, M.D. \\ Neurosurgical Clinic, Charité-Universitätsmedizin Berlin, Germany
}

\begin{abstract}
Intraoperative electrical stimulation of the motor cortex is a sensitive method for intraoperative mapping and monitoring of this region. Two different stimulation techniques have been established, the bipolar and monopolar techniques. Controversy exists regarding the most suitable method. Both methods have advantages and disadvantages and different electrophysiological backgrounds. The present study is a review of the electrophysiological basis of direct cortical electrical stimulation of the motor cortex. Both methods are discussed and their field of application is presented. (DOI: 10.3171/2009.8.FOCUS09141)
\end{abstract}

KEY WORDS • review - intraoperative monitoring • cortical stimulation

$\mathrm{T}$ HE intraoperative use of neurophysiological techniques allows reliable identification of the sensorimotor region, and constitutes a prerequisite for its anatomical and functional preservation. The clinical impact of IOM has been demonstrated in various pub-

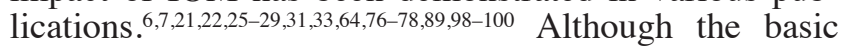
principle of cortical stimulation is the application of an electrical impulse on the cortex, two different methods have been established, the BCS and the MCS techniques. Recent literature shows a wide spectrum of application for both techniques, and a discussion is ongoing in which either method is favored. Therefore, controversy exists regarding the superiority of each method.

However, cortical electrical stimulation, especially in patients in whom general anesthesia has been induced, is a complex neurophysiological phenomenon. Both techniques are suitable to perform cortical stimulation; however, they differ in their electrophysiological parameters. The purpose of this manuscript was to present the basic mechanisms for both methods and to explain the differences in their effect on the motor cortical system.

\section{Mapping Methods}

\section{Bipolar Cortical Stimulation}

Fritsch and Hitzig ${ }^{41}$ first described the motor cortex as a functional unit in 1870, and since then many tech-

\footnotetext{
Abbreviations used in this paper: $\mathrm{BCS}=$ bipolar cortical stimulation; EPSP = excitatory postsynaptic potential; IOM = intraoperative monitoring; $\mathrm{MCS}=$ monopolar cortical stimulation; $\mathrm{MEP}=$ motor evoked potential; $\mathrm{PMC}=$ primary motor cortex; $\mathrm{SMC}=$ secondary motor cortex.
}

niques have been developed for direct electrical stimulation of motor cortex areas. Sir Victor Horsley ${ }^{52-54}$ triggered movements in the extremities of monkeys and later also of humans by electrically stimulating the cerebral cortex. Keen ${ }^{59-61}$ performed this procedure with the socalled double brain electrode, which consisted of a rubberized handpiece with two partially isolated end poles. A battery provided the current for stimulation.

Modifications of this technique and their application in patients undergoing awake surgery were described in subsequent decades by many authors, ${ }^{18,44,56,83}$ including Gruenbaum and Sherrington in 1903 as well as Cushing in 1909. However, it was the basic study published by Penfield and Boldrey ${ }^{83}$ in 1937 that established intraoperative cortex stimulation as a routine method in conscious patients. It should be noted, though, that this stimulation technique could not be applied in patients under general anesthesia.

It was only in 1991 that LeRoux et al. ${ }^{70}$ presented a modification of the stimulation method already applied by Penfield, which enabled direct cortex stimulation under general anesthesia. This bipolar stimulation technique has become a standard method in the meantime. ${ }^{5,36,37,62,72,73} \mathrm{~A}$ varying pulse sequence had been applied with a relatively low frequency of 50-60 Hz. Thus, King and Schell ${ }^{62}$ in 1987 reported on the application of a bipolar monophasic stimulation technique with a frequency of $50 \mathrm{~Hz}$. It became evident, however, that a sequence of 250-500 pulses was necessary to trigger an MEP. Comparable results were published by Ebeling et al. ${ }^{36,37}$ in 1989, and by Berger et al..$^{5,6}$ in 1990. The stimulation intensity needed to trigger an MEP, however, had a very high range (up to $40 \mathrm{~mA}$ ). Yingling et al. ${ }^{108}$ reported 


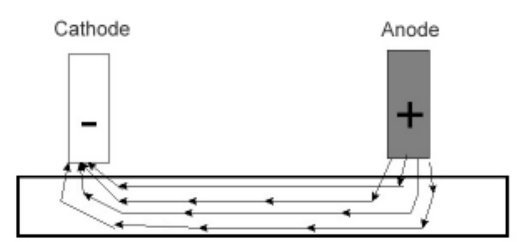

FIG. 1. Schematic representation of current flow following electrical stimulation of a nerve.

on precise localization of the motor centers with the aid of bipolar stimulation.

Extensive experience with this technique constitutes its major advantage. However, BCS does not allow an objective analysis. Furthermore, the movements elicited by the stimulation cause interference during microneurosurgery, thus preventing continuous monitoring of motor function during tumor resection. This is the major disadvantage of the method as compared with continuous monopolar stimulation. The rare induction of an intraoperative seizure by low-frequency stimulation is a further disadvantage of this technique.

Bipolar cortical stimulation is a sensitive method for mapping the motor cortex, especially the premotor frontal cortex. ${ }^{64}$ The effect of the bipolar stimulus is on the level of the cortex, making the method a standard technique for mapping cortical function. However, in several reports investigators used BCS for mapping of the subcortical pathways. As a mapping technique, this is the standard for cortical and subcortical mapping. ${ }^{25-28,30-34}$ Bipolar cortical stimulation is the only technique available today for the intraoperative mapping and monitoring of speech-related cortex.

\section{Monopolar Cortical Stimulation}

The choice of a monopolar stimulus is based on investigations performed by Hern, ${ }^{51}$ who examined the direct electrical excitability of pyramidal cells of the motor cortex and was the first author to propagate an anodic stimulation technique. These findings were confirmed by Gorman, ${ }^{42}$ who compared various techniques for direct stimulation of the cortex. Gorman demonstrated that direct monopolar anodic stimulation of the cortex required the lowest stimulation intensity to trigger an MEP. Ranck ${ }^{90}$ performed a series of electrophysiological investigations showing that anodic stimulation directly excites the axons of the pyramidal cells. The MEPs could be recorded in conscious patients by applying an anodic rectangular pulse with a duration of $0.2 \mathrm{msec}$ and a stimulation intensity ranging between 1 and $10 \mathrm{~mA}$.

In 1993, Taniguchi et al. ${ }^{101}$ described a further modification of the monopolar stimulation technique. A highfrequency $(300-500 \mathrm{~Hz})$ anodic rectangular pulse was used to record MEPs during surgery after induction of general anesthesia. The requisite stimulation intensity of $20 \mathrm{~mA}$ was markedly below that of low-frequency bipolar stimulation. Five pulses were needed to trigger an MEP. This count was lower by a factor of 50-100 than in the previously mentioned studies on bipolar stimulation. $5,36,37,62$

The monopolar anodic stimulus leads to excitation

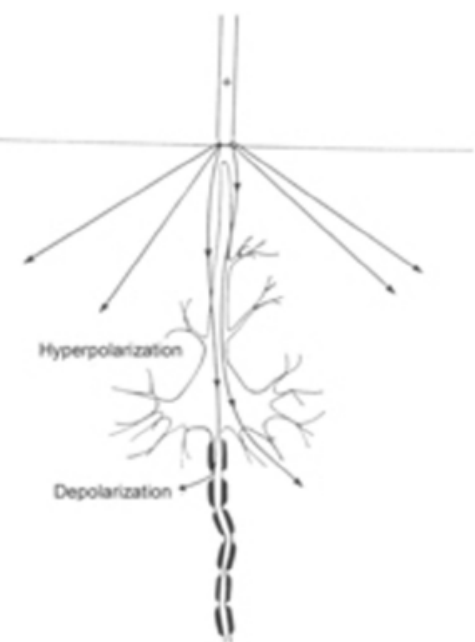

FIG. 2. Schematic representation of the effect of anodal monopolar stimulation on nerve cells.

of the pyramidal cell zone. The high-frequency pulse sequence leads to an accumulation of EPSPs. As demonstrated by Landgren et al. ${ }^{66}$ as well as by Day et al., ${ }^{19}$ a temporary accumulation of EPSPs is necessary to activate the resting motor neurons, even after induction of general anesthesia. ${ }^{102}$ When a stimulus has been transmitted via the synapse, so-called EPSPs are registered in the postsynaptic membrane. ${ }^{11}$ The EPSPs indicate the depolarization of the postsynaptic cell, which can last for up to $20 \mathrm{msec}$. An action potential is produced as soon as the membrane potential exceeds the threshold value of $-60 \mathrm{mV}$. Two temporally separate stimuli reaching the synapse produce 2 EPSPs; these can accumulate and thus increase the membrane potential. An action potential is the result of this accumulation.

A series of tests ${ }^{101}$ in 9 patients showed that MCS provides a simple technique for low-intensity stimulation of the motor cortex. Repetitive stimulation could be performed throughout the entire operation. The short repetition time enabled surgical maneuvers to be correlated with changes in the MEPs. In 1996, Cedzich et al. ${ }^{17}$ demonstrated the practicability of motor cortex mapping (in 33 patients) as well as intraoperative monitoring (in 25 patients). The intraoperative application of this neurophysiological examination technique has failed thus far due to lack of experience.

Monopolar cortical stimulation has been proven to be a reliable method for monitoring subcortical pathways. Changes in MEP latency and amplitude serve as warning criteria during surgery and are of prognostic value. ${ }^{64,97,98}$

\section{Neurophysiological Basis}

The electrical resistance and capacity of the pia mater are not measurable after a few minutes of air exposure. ${ }^{4}$ Electrical resistance is 4-6 times higher in the gray than in the white matter. ${ }^{3,79,91}$ According to Ohm's law, these different resistances influence the flow of current. After electrical stimulation of a nerve fiber, the current flows inward at the positive electrode (anode) and outward at the negative one (cathode) (Fig. 1). ${ }^{88}$ 


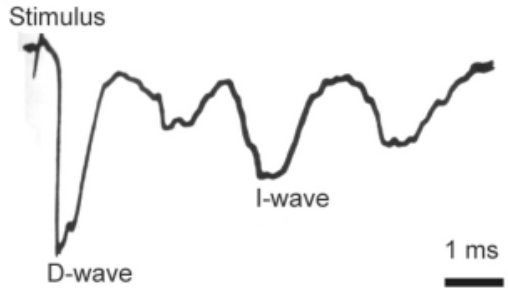

FIG. 3. Chart showing epidural recordings following monopolar stimulation.

The extracellular space becomes negative at the cathode, thus increasing the intra/extracellular electrical gradients. This potential difference at the membrane leads to depolarization..$^{90}$ The cell membrane is depolarized at the cathode by the outward flow of current but hyperpolarized at the anode by its inward flow. ${ }^{85,88}$ Because a hyperpolarized membrane is refractory, too high a hyperpolarization will block conduction. Therefore, a depolarization generated below the cathode can only be conducted when the hyperpolarization at the anode is not too high. ${ }^{90}$ Hence, a monopolar cathodic stimulation is conducted at low but not at suprathreshold intensities. ${ }^{57}$

Axons have a lower stimulation threshold than dendrites. ${ }^{40,90}$ Hern et al ${ }^{51}$ demonstrated that anodic stimulation of the motor cortex leads to stimulation of the pyramidal cells. The anodic flow enters the dendrites, causes hyperpolarization, and exits the axon, where it produces depolarization (Fig. 2).

Electrical stimulation of the pyramidal cells results in a 2-stage conduction of the pulse through the tract. ${ }^{80}$ First a wave (the so-called D wave) is registered directly after the stimulus. The D wave is caused by direct stimulation of the pyramidal tract. This is followed by a delayed series of waves (the so-called I waves). Apart from having a direct effect on the axons, the stimulus also leads to an indirect repetitive conduction in the pyramidal tract (I waves) (Fig. 3). Isolated destruction of the gray matter leads to extinction of the I waves, but the $\mathrm{D}$ wave remains unchanged. ${ }^{81}$

In humans, conduction is slow in $90 \%$ of the pyramidal fibers (thickness of $1-4 \mu \mathrm{m})^{68}$ and rapid in only $1.7 \%$ (thickness 11-22 $\mu \mathrm{m}$ ). Between 60 and $94 \%$ of the fibers are myelinated. ${ }^{23,68}$ The conduction rate of pyramidal fibers varies between 50 and $80 \mathrm{~m} /$ second. $^{68}$

Experimental studies in animals have shown that anodic stimulation of the motor cortex produces a D-wave response, whereas cathodic stimulation elicits a pure Iwave response (without D wave). ${ }^{51}$ Gorman $^{42}$ observed that a cathodic stimulus leads to a measurable latency prolongation of 100-150 usec in the medulla oblongata.

The EPSPs produced after an anodic stimulus are not only accumulated but also enhanced by the pulse sequence. ${ }^{85}$ The high-frequency pulse sequence has the effect of generating not only D but also I waves, particularly after the third stimulus of the sequence. Intracortical connections conduct the stimulus into adjacent neurons, which in turn react with an I response. This results in the aforementioned enhancement of EPSPs following a monopolar anodic high-frequency stimulus and renders anodic more effective than cathodic MCS.

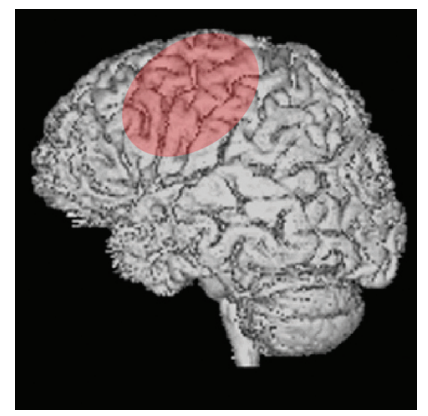

FIG. 4. A 3D reconstruction showing distribution of hand motor areas identified by BCS and MCS.

A bipolar stimulus is more effective with the stimulation electrodes aligned transversally, rather than longitudinally, to the axon..$^{92}$ Nathan et al. ${ }^{75}$ demonstrated that maximal focusing of the current density $\left(\mathrm{A} / \mathrm{cm}^{2}\right)$ is achieved by spherical electrodes at a distance of $5 \mathrm{~mm}$. The current density is at its maximum directly below the electrode $\left(0.05 \mathrm{~A} / \mathrm{cm}^{2}\right)$ when applying bipolar stimulation with a current intensity of $10 \mathrm{~mA}\left(0.05 \mathrm{~A} / \mathrm{cm}^{2}\right)$. The current spreads in a laminar fashion and decreases with increasing distance from the stimulation electrode. With a monopolar stimulus, the flow of current decreases with increasing distance from the center of the electrode.

Experimental studies in animals ${ }^{109}$ have shown that high levels of continuous electrical stimulation result in gliosis, with glycogen accumulation. Neuron destruction has even been observed in severe cases. On the cellular level, the increased intracellular $\mathrm{Ca}^{++}$and lipid concentrations were found to result in destruction of the cell membrane and neurons. .,2,71,109 $^{2}$

The current flowing into the cortex via the electrode elicits an electrochemical reaction that alters tissue $\mathrm{pH}$ and leads to organic oxidation. ${ }^{71}$ In addition, the flow of current through the neurons causes neuronal hyperactivity, which impairs cellular homeostasis through a change in the intra- and extracellular concentration of $\mathrm{K}+$ and $\mathrm{Ca}^{++}$. A destruction of the cell membrane may result from this reaction. Thus the current density should not exceed $40 \mu \mathrm{C} / \mathrm{cm}^{2}$ when applying continuous stimulation. ${ }^{2,74,86,87}$

However, all these studies were performed during continuous stimulation (1.5-50 hours). There have not yet been any investigations describing the effects of intraoperative electrical stimulation on the human brain. Epileptic seizures must be attributed to electrical stimulation and not to neuronal damage. ${ }^{86,87,109}$

\section{Discussion}

Contrary to the general view, there is considerable functional spreading of motor units throughout a much wider area than the classic narrow cortical strip along the central sulcus (Fig. 4). In a mapping study combining bipolar and monopolar stimulation of all motor responses elicited by BCS, $54.28 \%$ were located in the PMC, $37.85 \%$ outside the motor strip in the SMC, and $8 \%$ posterior to the central sulcus. Of all motor responses elicited by MCS, $68.57 \%$ were located in the PMC, $23.42 \%$ in the SMC, and $8 \%$ posterior to the central sulcus. ${ }^{65}$ 
Humans and nonhuman primates are assumed to have at least 4 different motor areas: the PMC; the premotor cortex; the SMC; and the cingulate gyrus. $8,9,20,43,55,58,67$, $69,80,84,93,94,96$ Thus, anatomical orientation must, whenever possible, be complemented by intraoperative mapping of all these areas to prevent postoperative motor deficits.

The common histological denominator of the motor cortex in human and nonhuman primate brains is the agranular cytoarchitectonic pattern characterized by the Betz cells in the PMC and the rostrally adjoining frontal cortex. The agranular region is bordered rostrally by the prefrontal cortex and caudally by the granular somatosensory cortex. The cingulate gyrus marks the border of the agranular isocortex. ${ }^{104,105}$ In humans, parts of the cingulate cortex beneath the supplementary motor area are activated during various motor paradigms. ${ }^{82,96}$

Neurologists and psychiatrists took an early interest in localizing cerebral functions. Clinicians thus made the first attempts at localization. Broca ${ }^{10}$ found a lesion at the foot of the third frontal gyrus while performing an autopsy in a patient who had suffered from a speech disorder. Wernicke ${ }^{107}$ detected damage in the dorsal segment of the first parietal gyrus in a patient with a word comprehension disorder.

Stimulation experiments ${ }^{39,41}$ revealed a functional segmentation in the precentral gyrus. Dusser de Barenne ${ }^{35}$ performed animal experiments in which the stimulant was not an electric current but strychnine applied to circumscribed regions of the postcentral gyrus. He found that after this procedure the animal scratched a certain body region. The postcentral gyrus could be functionally analyzed in this way.

Kleist, a student of Wernicke, drew up a "structural and functional map of the brain" based on his long-term experience, his observation of 300 World War I braininjury victims, and his assessment of 106 circumscribed cerebral lesions examined in his own clinic. ${ }^{63}$ Referring in this connection to the research results of Campbell, ${ }^{15}$ Smith, ${ }^{95}$ Brodmann, $, 2,13$ Vogt, ${ }^{106}$ Economo, ${ }^{38}$ Cajal, ${ }^{14}$ and van Valkenburg, ${ }^{103}$ he linked various regions with the cytoarchitectural fields of Brodmann. ${ }^{12}$

The knowledge gained by animal experiments was confirmed and even broadened during neurosurgical interventions. ${ }^{18}$ The introduction of stereotactic methods yielded new findings. ${ }^{45-50}$ Stereotactic surgery made it possible to stimulate or disconnect even deep structures and to record evoked potentials from particular brain centers by using implanted microelectrodes.

Rudin and Eisenman ${ }^{92}$ demonstrated that bipolar stimulation is more effective if the electrodes are transversely oriented rather than longitudinally to the surface of the cortex. Nathan et al. ${ }^{75}$ found that current density (A/ $\mathrm{cm}^{2}$ ) can be focused during bipolar stimulation by placing spherical electrodes $5 \mathrm{~mm}$ apart. This is why in our own series a bipolar stimulation probe with 2 spherical steel electrodes $5 \mathrm{~mm}$ apart was used. During BCS with $10 \mathrm{~mA}$, the current peaks in the region directly below the bipolar electrodes $\left(0.05 \mathrm{~A} / \mathrm{cm}^{2}\right)$.

When monopolar anodal stimulation is applied, current density decreases much less rapidly with depth. ${ }^{75}$ Several studies have shown that an anode is more effec- tive for MCS than a cathode ${ }^{85,88}$; anodal current enters and hyperpolarizes dendrites, and leaves and depolarizes the axon or cell body. ${ }^{88}$ Hern et al. ${ }^{51}$ have demonstrated a direct action of monopolar anodal stimulation on pyramidal cells. This is due to the fact that the axon and regions adjacent to the cell body have a much lower threshold than the dendrites and the cell body. ${ }^{90}$

Repetitive MCS induces repetitive excitation of the corticospinal tract. ${ }^{101}$ The high-frequency train achieves an accumulation of postsynaptic potentials, which activates the motor neurons even after induction of general anesthesia.

Intraoperative mapping requires frequent stimulation throughout the procedure. A bipolar stimulus lasts 2-4 seconds, as compared with the 1.4 msec needed for a monopolar stimulus. In addition to the difficulty in evaluating movement quantitatively, the increased stimulus duration prolongs the monitoring procedure.

The method of MCS requires a high-frequency electrical stimulus. No intraoperative seizures occur as a result of the stimulation. ${ }^{16,64,98}$ The major advantage of this new technique is that it allows objective analysis of the results. The motor responses recorded during surgery can be analyzed regarding latency, amplitude, and duration. Because MCS never causes movements, it may be used repeatedly.

\section{Conclusions}

Monopolar cortical stimulation has been proven to be a reliable method for monitoring subcortical pathways, and is just as sensitive as BCS for mapping the PMC. Changes in MEP latency and amplitude serve as warning criteria during surgery and are of prognostic value. The monopolar anodic stimulus leads to excitation of the pyramidal tract.

Bipolar cortical stimulation is a sensitive method for mapping the motor cortex, especially the premotor frontal cortex. The effect of the bipolar stimulus is on the level of the cortex, making the method a standard technique for mapping cortical and subcortical function. The only technique available today for the intraoperative mapping and monitoring of speech-related cortex is BCS. Surgery in the SMC requires a combination of bipolar stimulation for mapping and monopolar stimulation for monitoring the descending motor pathways.

\section{Disclaimer}

The authors report no conflict of interest concerning the materials or methods used in this study or the findings specified in this paper.

\section{References}

1. Agnew WF, McCreery D: Considerations for safety in the use of electrical stimulation for motor evoked potentials. Neurosurgery 20:143-147, 1987

2. Agnew WF, Yuen TGH, Pudenz RH, Bullara LA: Electrical stimulation of the brain: IV. Ultrastructural studies. Surg Neurol 4:438-448, 1975

3. Axer H, Stegelmeyer J, Graf von Kayserlingk D: Comparison of tissue impedance measurements with nerve fiber architec- 
ture in human telencephalon: value in identification of intact subcortical structures. J Neurosurg 90:902-909, 1999

4. Bennett MVL: Electrical impedance of brain surfaces. Brain Res 15:584-590, 1969

5. Berger MS, Cohen WA, Ojemann GA: Correlation of motor cortex brain mapping data with magnetic resonance imaging. J Neurosurg 72:383-387, 1990

6. Berger MS, Ojemann GA, Lettich E: Neurophysiological monitoring during astrocytoma surgery. Neurosurg Clin $\mathbf{N}$ Am 1:65-80, 1990

7. Berger MS, Rostomily RC: Low grade gliomas: functional mapping resection strategies, extent of resection, and outcome. J Neurooncol 34:85-101, 1997

8. Boecker H, Khorram-Sefat D, Kleinschmidt A, Merbold KD, Haenicke W, Requardt M, et al: High-resolution functional magnetic resonance imaging of cortical activation during tactile exploration. Hum Brain Mapp 3:236-244, 1995

9. Boecker H, Kleinschmidt A, Requardt M, Haenicke W, Merbold KD, Frahm J: Functional cooperativity of human cortical motor areas during self-paced finger movements: a high-resolution MRI study. Brain 117:1231-1239, 1994

10. Broca P: Remarques sur la siège de la faculté du langage articulé. Bull Soc Anat Paris 36:330-357, 1861

11. Brock LG, Coombs JS, Eccles JC: The recording of potentials from the motoneurons with an intracellular electrode. J Physiol 117:431-460, 1952

12. Brodmann K: Beiträge zur histologischen Lokalisation der Großhirnrinde. VI Mitteilung. Die Cortexgliederung des Menschen. J Psychol Neurol 10:231-246, 1908

13. Brodmann K: Vergleichende Lokalisationslehre der Großhirnrinde. Leipzig: Barth, 1909

14. Cajal SR: Histologie du système nerveux de l'homme et des vertébrés. Paris: Maloine, 1911

15. Campbell AW: Histological studies on the Localisation of Cerebral Function. Cambridge: Cambridge University Press, 1905

16. Cedzich C, Pechstein U, Schramm J, Schäfer S: Electrophysiological considerations regarding electrical stimulation of motor cortex and brain stem in humans. Neurosurgery 42:527-532, 1998

17. Cedzich C, Taniguchi M, Schäfer S, Schramm J: Somatosensory evoked potential phase reversal and direct motor cortex stimulation during surgery in and around the central region. Neurosurgery 38:962-970, 1996

18. Cushing H: A note upon the Faradic stimulation of central gyrus in conscious patients. Brain 32:42-53, 1909

19. Day BL, Rothwell JC, Thompson PD, Dick J, Cowan JM, Barardelli A, et al: Motor cortex stimulation in intact man. 2. Multiple descending volleys. Brain 110:1191-1209, 1987

20. Decety J, Perani D, Jeannerod M, Bettinardi V, Tadary B, Woods RP, et al: Mapping motor representations with positron emission tomography. Nature 371:600-602, 1994

21. Deletis V: Intraoperative monitoring of the functional integrity of the motor pathway. Adv Neurol 63:201-214, 1993

22. Deletis V, Kothbauer K: Intraoperative neurophysiology of the corticospinal tract, in Stålberg E, Sharma HS, Olson Y (eds): Spinal Cord Monitoring. Vienna: Springer Verlag, 1998, pp 421-444

23. DeMeyer W: Number of axons and myelin sheaths in adult human medullary pyramids: study with silver impregnation and iron hematoxylin staining methods. Neurology 9:42-47, 1959

24. Duffau H: Brain plasticity and tumors. Adv Tech Stand Neurosurg 33:3-33, 2008

25. Duffau H: Contribution of cortical and subcortical electrostimulation in brain glioma surgery: methodological and functional considerations. Neurophysiol Clin 37:373-382, 2007

26. Duffau H: Intraoperative cortico-subcortical stimulations in surgery of low-grade gliomas. Expert Rev Neurother 5:473485, 2005

27. Duffau H: Lessons from brain mapping in surgery for lowgrade glioma: insights into associations between tumour and brain plasticity. Lancet Neurol 4:476-486, 2005

28. Duffau H: New concepts in surgery of WHO grade II gliomas: functional brain mapping, connectionism and plasticity-a review. J Neurooncol 79:77-115, 2006

29. Duffau H: A personal consecutive series of surgically treated 51 cases of insular WHO Grade II glioma: advances and limitations. J Neurosurg110:696-708, 2009 [epub ahead of print January 9, 2009. DOI: 10.3171/2008.8.JNS08741]

30. Duffau H, Gatignol P, Mandonnet E, Peruzzi P, Tzourio-Mazoyer N, Capelle L: New insights into the anatomo-functional connectivity of the semantic system: a study using corticosubcortical electrostimulations. Brain 128:797-810, 2005

31. Duffau H, Leroy M, Gatignol P: Cortico-subcortical organization of language networks in the right hemisphere: an electrostimulation study in left-handers. Neuropsychologia 46:3197-3209, 2008

32. Duffau H, Lopes M, Arthuis F, Bitar A, Sichez JP, Van Effenterre R, et al: Contribution of intraoperative electrical stimulations in surgery of low grade gliomas: a comparative study between two series without (1985-96) and with (1996-2003) functional mapping in the same institution. J Neurol Neurosurg Psychiatry 76:845-851, 2005

33. Duffau H, Gatignol P, Mandonnet E, Capelle L, Taillandier L: Intraoperative subcortical stimulation mapping of language pathways in a consecutive series of 115 patients with Grade II glioma in the left dominant hemisphere. J Neurosurg 109:461-471, 2008

34. Duffau H, Thiebaut de Schotten M, Mandonnet E: White matter functional connectivity as an additional landmark for dominant temporal lobectomy. J Neurol Neurosurg Psychiatry 79:492-495, 2008

35. Dusser de Barenne JG: Experimental researches on sensory locations in the cerebral cortex. J Exp Physiol 9:355-390, 1916

36. Ebeling U, Schmid UD, Reulen HJ: Tumour surgery within the central motor strip: surgical results with aid of electrical motor cortex stimulation. Acta Neurochir (Wien) 101:101107, 1989

37. Ebeling U, Schmid UD, Ying H, Reulen HJ: Safe surgery of lesions near the motor cortex using intra-operative mapping techniques: a report on 50 patients. Acta Neurochir (Wien) 119:23-28, 1992

38. Economo C, Koskinas N: Die Cytoarchitektonik der Hirnrinde des erwachsenen Menschen. Wien: Springer, 1925

39. Ferrier D: The Function of the Brain. London: Smith \& Elder, 1876

40. Frank K, Fuortes MGF: Stimulation of spinal motoneurons with intracellular electrodes. J Physiol 134:451-470, 1956

41. Fritsch G, Hitzig E: Über die elektrische Erregbarkeit des Grosshirns. Arch Anat Physiol (Wiss Med) 37:300-332, 1870

42. Gorman ALF: Differential patterns of activation of the pyramidal system elicited by surface anodal and cathodal cortical stimulation. J Physiol 29:547-564, 1966

43. Grafton ST, Fagg AH, Woods RP, Arbib MA: Functional anatomy of pointing and grasping in humans. Cereb Cortex 6:226-237, 1996

44. Gruenbaum A, Sherrington C: Observations on physiology of the cerebral cortex of some of the higher apes. Proc R Soc Lond B Biol Sci 72:152-209, 1903

45. Hassler R: Die extrapyramidalen Rindensysteme und die zentrale Regelung der Motorik. Dtsch Z Nervenheilkd 175: 233-258, 1956

46. Hassler R: Fiber connections within the extrapyramidal system. Confin Neurol 36:237-255, 1974 
47. Hassler R: Motorische und sensible Effekte umschriebener Reizungen und Ausschaltungen im menschlichen Zwischenhirn. Dtsch Z Nervenheilkd 183:148-171, 1961

48. Hassler R: Spezifische und unspezifische Systeme des menschlichen Zwischenhirns. Prog Brain Res 5:1-32, 1964

49. Hassler R: Zur funktionellen Anatomie des limbischen Systems. Nervenarzt 35:386-396, 1964

50. Hassler R, Riechert T: Klinische und anatomische Befunde bei stereotaktischen Schmerzoperationen im Thalamus. Arch Psychiatr Nervenkr 200:93-122, 1959

51. Hern JE, Landgren S, Phillips CG, Porter R: Selective excitation of corticofugal neurones by surface-anodal stimulation of the baboon's motor cortex. J Physiol 161:73-90, 1962

52. Horsley V: The Croonian Lecture: On the mammalian nervous system, its functions and their localization, determined by an electrical method. Philos Trans R Soc Lond B Biol 182: 267-326, 1891

53. Horsley V, Schäfer EA: Experimental researches in cerebral physiology: I. On the functions of the marginal convolution. Proc R Soc Lond B Biol Sci 36:437-442, 1883-1884

54. Horsley V, Schäfer EA: I. A record of experiments upon the functions of the cerebral cortex. Philos Trans R Soc Lond B Biol 179:1-45, 1888

55. Jahanshahi M, Jenkins IH, Brown RG, Marseden CD, Passingham RE, Brooks DJ: Self-initiated versus externally triggered movements. I. An investigation using measurement of regional blood flow with PET and movement related potentials in normal and Parkinson's disease subjects. Brain 118:913-933, 1995

56. Jasper H, Lende R, Rasmussen T: Evoked potentials from the exposed somatosensory cortex in man. J Nerv Ment Dis 130:526-537, 1960

57. Katz B, Miledi R: Propagation of electrical activity in motor nerve terminals. Proc R Soc Lond B Biol Sci 161:453-482, 1965

58. Kawashima R: O'Sullivan BT, Roland PE: Fields in human motor areas involved in preparation for reaching, actual reaching and visuomotor learning: a positron emission tomography study. J Neurosci 14:3462-3474, 1994

59. Keen WW: Three successful cases of cerebral surgery. Am J Med Sci 96:452-464, 1888

60. Keen WW, Gray H: Cerebral localization and topography, in Anatomy: Descriptive and Surgical. Philadelphia: Lea Brothers, 1887, pp 681-684

61. Keen WW, White JW: Topography of the brain in its surgical relations, in An American Textbook of Surgery for Practitioners and Students. Philadelphia: W.B. Saunders, 1903, pp 548-554

62. King RB, Schell GR: Cortical localization and monitoring during cerebral operations. J Neurosurg 67:210-219, 1987

63. Kleist K: Gehirnpathologie, in Handbuch der ärztlichen Erfahrungen im Weltkrieg 1914/18, Bd. IV. Leipzig: Barth, 1922

64. Kombos T, Suess O, Ciklatekerlio O, Brock M: Monitoring of intraoperative motor evoked potentials to increase the safety of surgery in and around the motor cortex. J Neurosurg 95:608-614, 2001

65. Kombos T, Suess O, Kern BC, Funk T, Hoell T, Kopetsch O, et al: Comparison between monopolar and bipolar electrical stimulation of the motor cortex. Acta Neurochir (Wien) 141:1295-1301, 1999

66. Landgren S, Phillips CG, Porter R: Minimal synaptic actions of pyramidal impulses on some alpha-motoneurons of the baboon's hand and forearm. J Physiol 161:91-111, 1962

67. Larsson J, Gulyas B, Roland PE: Cortical representation of self-paced finger movement. Neuroreport 7:463-468, 1996

68. Lassek AM: The pyramidal tract: the effect of pre- and postcentral cortical lesions on the fiber components of the pyramids in monkey. J Nerv Ment Dis 95:721-729, 1942

69. Leonardo M, Fieldman J, Sadato N, Campbell G, Ibanez V,
Cohen L, et al: A functional magnetic resonance imaging study of cortical regions associated with motor task execution and motor ideation in humans. Hum Brain Mapp 3:83-92, 1995

70. LeRoux PD, Berger MS, Haglund MM, Pilchner WH, Ojemann GA: Resection of intrinsic tumors from nondominant face motor cortex using stimulation mapping: report of two cases. Surg Neurol 36:44-48, 1991

71. McCreery DB, Agnew W: Changes in extracellular potassium and calcium concentration and neural activity during prolonged electrical stimulation of the cat cerebral cortex at defined charge densities. Exp Neurol 79:371-396, 1983

72. Merton PA, Morton HB: Stimulation of the human cortex in the intact human subject. Nature 285:227, 1980

73. Merton PA, Morton HB, Hill DK, Marseden CD: Scope of a technique for electrical stimulations of human brain, spinal cord and muscles. Lancet 2:597-600, 1982

74. Mortimer JT, Shealy CN, Wheeler C: Experimental non-destructive electrical stimulation of the brain and spinal cord. J Neurosurg 32:553-559, 1970

75. Nathan SS, Sinha SR, Gordon B, Lesser RP, Thakor NV: Determination of current density distributions generated by electrical stimulation of the human cerebral cortex. Electroencephalogr Clin Neurophysiol 86:183-192, 1993

76. Neuloh G, Pechstein U, Cedzich C, Schramm J: Motor evoked potential monitoring with supratentorial surgery. Neurosurgery 61:337-338, 2007

77. Neuloh G, Pechstein U, Schramm J: Motor tract monitoring during insular glioma surgery. J Neurosurg 106:582-592, 2007

78. Neuloh G, Schramm J: Monitoring of motor evoked potentials compared with somatosensory evoked potentials and microvascular Doppler ultrasonography in cerebral aneurysm surgery. J Neurosurg 100:389-399, 2004

79. Nicholson PW: Specific impedance of cerebral white matter. Exp Neurol 13:386-401, 1965

80. Parsons LM, Fox PT, Downs H, Glass T, Hirsch TB, Martin $\mathrm{CC}$, et al: Use of implicit motor imagery for visual shape discrimination as revealed by PET. Nature 375:54-58, 1995

81. Patton HD, Amassian VE: Single- and multiple-unit analysis of cortical stage of pyramidal tract activation. J Neurophysiol 17:345-363, 1954

82. Paus T, Petrides M, Evans AC, Meyer E: Role of human anterior cingulate cortex in the control of oculomotor, manual, and speech responses: a positron emission tomography study. J Neurophysiol 70:453-469, 1993

83. Penfield W, Boldrey E: Somatic motor and sensory representation in the cerebral cortex of man as studied by electrical stimulation. Brain 60:389-443, 1937

84. Penfield W, Welch K: The supplementary motor area of the cerebral cortex. AMA Arch Neurol Psychiatry 66:289-317, 1951

85. Phillips CG, Porter R: Unifocal and bifocal stimulation of the motor cortex. J Physiol 162:532-538, 1962

86. Pudenz RH, Bullara LA, Dru D, Talalla A: Electrical stimulation of the brain: II. Effects on the blood-brain barrier. Surg Neurol 4:265-270, 1975

87. Pudenz RH, Bullara LA, Jacques S, Hambrecht FT: Electrical stimulation of the brain: III. The neural damage model. Surg Neurol 4:389-400, 1975

88. Purpura DP, McMurty JG: Intracellular activities and evoked potential changes during polarization of motor cortex. J Neurophysiol 28:166-185, 1965

89. Quinones-Hinojosa A, Ojemann S, Sanai N, Dillon WP, Berger MS: Preoperative correlation of intraoperative cortical mapping with magnetic resonance imaging landmarks to predict localization of Broca area. J Neurosurg 99:311-318, 2003

90. Ranck JB Jr: Which elements are excited in electrical stimulation 


\section{Review of intraoperative mapping methods}

of mammalian central nervous system: a review. Brain Res 98:417-440, 1975

91. Ranck JB Jr, BeMent SL: The specific impedance of the dorsal columns of cat: an anisotopic medium. Exp Neurol 11:451-463, 1965

92. Rudin DO, Eisenman G: The action potential of spinal axons in vitro. J Gen Physiol 37:505-538, 1954

93. Schlaug G, Knorr U, Seitz RJ: Inter-subject variability of cerebral activations in acquiring a motor skill: a study with positron emission tomography. Exp Brain Res 98:523-534, 1994

94. Seitz RJ, Canavan AG, Yágüez L, Herzog H, Tellmann L, Knorr $\mathrm{U}$, et al: Successive roles of the cerebellum and premotor cortices in trajectorial learning. Neuroreport 5:2541-2544, 1994

95. Smith E: A new topographical survey of the cerebral cortex being on the account of the distribution on the anatomical distinct cortical areas and their relationship to the cerebral sulci. J Appl Physiol 41:237-254, 1907

96. Stephan KM, Fink GR, Passingham RE, Silbersweig D, CeballosBaumann AO, Frith CD, et al: Functional anatomy of the mental representation of upper extremity movements in healthy subjects. J Neurophysiol 73:373-386, 1995

97. Suess O, Ciklatekerlio Ö, Suess S, Da Silva C, Brock M, Kombos $\mathrm{T}$ : [Clinical studies on the use of high frequency monopolar cortex stimulation for intraoperative monitoring and localization of motor function centers in surgery of the central region of the brain.] Klin Neurophysiol 34:127-137, 2003 (Ger)

98. Suess O, Suess S, Brock M, Kombos T: Intraoperative electrocortical stimulation of Brodman area 4: a 10-year analysis of 225 cases. Head Face Med 2:1-13, 2006

99. Szelényi A, Bueno de Camargo A, Flamm E, Delitis V: Neurophysiological criteria for intraoperative prediction of pure motor hemiplegia during aneurysm surgery. Case report. J Neurosurg 99:575-578, 2003

100. Szelényi A, Kothbauer K, Bueno de Camargo A, Langer D, Flamm ES, Delitis V: Motor evoked potential monitoring during cerebral aneurysm surgery: technical aspects and comparison of transcranial and direct cortical stimulation. J Neurosurg $\mathbf{5 7 : 3 3 1 - 3 3 8 , 2 0 0 5}$
101. Taniguchi M, Cedzich C, Schramm J: Modification of cortical stimulation for motor evoked potentials under general anesthesia: technical description. Neurosurgery 32:219-226, 1993

102. Taniguchi M, Nadstawek J, Langenbach U, Bremer F, Schramm $\mathrm{J}$ : Effects of four anesthetic agents on motor evoked potentials elicited by magnetic transcranial stimulation. Neurosurgery 33: $407-415,1993$

103. Valkenburg van CT: Zur fokalen Lokalisation der Sensibilität in der Groáhirnrinde des Menschen. Z Ges Neurol Psychiat 24:294-312, 1914

104. Vogt BA, Gabriel M: Structural organisation of cingulate cortex: areas, neurons, and somatodentric transmitter receptors, in Neurobiology of Cingulate Cortex and Limbic Thalamus. Boston: Birkhauser, 1993, pp 19-70

105. Vogt BA, Nimchinsky EA, Vogt LJ, Hof PR: Humans cingulate cortex: surface features, flat maps, and cytoarchitecture. J Comp Neurol 359:490-506, 1995

106. Vogt C, Vogt O: Allgemeine Ergebnisse unserer Hirnforschung. J Psychol Neurol 25:279-461, 1919

107. Wernicke C: Der aphasische Symptomkomplex, eine psychologische Studie auf anatomischer Basis. Bresgau: Crohn \& Weigert, 1874

108. Yingling CD, Ojemann S, Dodson B, Harrington MJ, Berger MS: Identification of motor pathways during tumor surgery facilitated by multichannel electromyographic recording. J Neurosurg 91:922-927, 1999

109. Yuen TGH, Agnew W, Bullara LA, Jacques S, McCreery D: A histological evaluation of neural damage from electrical stimulation: considerations for the selection of parameters for clinical application. Neurosurgery 9:292-299, 1981

Manuscript submitted June 14, 2009.

Accepted August 19, 2009.

Address correspondence to: Theodoros Kombos, M.D., Neurosurgical Clinic, Charité-Universitätsmedizin Berlin, Hindenburgdamm 30, 12200 Berlin, Germany. email: theodoros.kombos@ charite.de. 